\title{
64. Biosynthesis of the Neuron-Specific Enolase (14.3.2 Protein) in a Cell Free System from Wheat Germ Extract Directed with Poly(A)-Containing RNA from Rat Brain
}

\author{
By Kenji SAkimura,*) Yutaka Yoshida,*) Yo-ichi Nabeshima,**) \\ and Yasuo TAKahashi*)
}

(Communicated by Setsuro EBAsHr, M. J. A., June 12, 1979)

14-3-2 Protein is a brain-specific protein found by Moore. ${ }^{1)}$ It was found to be localized in neurons and to be composed of two identical subunits of 40000-50000 daltons in molecular weight. A recent study revealed that enolase (2-phospho-D-glycerate hydrolase, EC 4.2.1.11) activity was associated with 14-3-2 protein. ${ }^{2)}$ Thus, Marangos et $\left.a l .{ }^{3}\right)$ designated it the neuron-specific enolase (NSE). From the usefulness of this protein as a marker in studies of cell differentiation in the nervous system, we have attempted to examine mRNA for 143-2 protein. There has as yet been no report on the biosynthesis of 14-3-2 protein in heterologous translating systems programmed with polysomal poly (A)-containing RNA from brain. In this paper we describe the synthesis of this protein in a wheat germ cell free system directed with brain mRNA.

Materials and methods. Wheat germ was obtained from Nisshin Mill Corp., Tokyo, Japan. $\left[4,5-^{3} \mathrm{H}\right]$ Leucine $(200 \mathrm{Ci} / \mathrm{mmol})$ was obtained from Radiochemical Centre, Amersham, England. Oligo (dT)cellulose (T2) was purchased from Collaborative Research, Waltham, Mass., U.S.A.

Purification of 14-3-2 protein. 14-3-2 Protein was purified from adult rat brain according to a modification of Grasso et $a l_{.}{ }^{4}$ ) and Marangos $e t ~ a l .{ }^{5}$ ) using enolase activity as a marker. Antisera against 14-3-2 protein were prepared with white rabbits.

Isolation of poly $(A)$-containing $R N A$. Free polysomes were prepared from adult rat brains according to a modified method of Takahashi et al. ${ }^{6)}$ Polysomal RNA was extracted with $0.5 \%$ SDSphenol-chloroform and deproteinized with chloroform-isoamylalcohol (24:1) by the method of Perry et al. ${ }^{7)}$ Polysomal RNA was dissolved in $0.5 \mathrm{M} \mathrm{KCl}, 10 \mathrm{mM}$ Tris-HCl $(\mathrm{pH} \mathrm{7.5)}$ and the poly (A)-containing

*) Department of Neuropharmacology, Brain Research Institute, Niigata University, Niigata, Japan.

**) Department of Biochemistry, Niigata University School of Medicine, Niigata, Japan. 
RNA was isolated by two cycles of oligo (dT) -cellulose affinity chromatography. ${ }^{8}$ Liver poly (A)-containing RNA was isolated from liver total polysomes by the same method.

Wheat germ cell free protein synthesis. Wheat germ extracts were prepared according to the method by Roberts and Patterson with some modification.9) The reaction mixture for cell free protein synthesis (final volume: $50 \mu \mathrm{l}$ ) usually contained $15 \mu \mathrm{l}$ of wheat germ extract, $1.5 \mathrm{mM}$ ATP, $0.3 \mathrm{mM}$ GTP, $3 \mathrm{mM}$ dithiothreitol, $16.5 \mathrm{mM}$ creatine phosphate, $320 \mu \mathrm{g} / \mathrm{ml}$ creatine kinase, $0.12 \mathrm{mM}$ concentration of each of 19 unlabeled amino acids without leucine, $0.8 \mathrm{mM}$ spermidine phosphate and $15 \mathrm{mM}$ HEPES-KOH (pH 7.6). [ $\left.{ }^{3} \mathrm{H}\right]$ Leucine, $\mathrm{KCl}$, magnesium acetate and RNA were added as indicated in each experiment. The reaction mixtures were incubated at $23^{\circ} \mathrm{C}$ for $90 \mathrm{~min}$. Aliquots of $5 \mu \mathrm{l}$ were pipetted onto $2.5 \mathrm{~cm}$ discs of Whatman $3 \mathrm{MM}$ paper, dried, washed with hot and cold 5\% TCA, ethanol, ethanolether $(3: 1)$ and ether. The filters were transferred into the scintillation vials and counted in a toluene-PPO scintillator by a Beckman LS-100 liquid scintillation spectrometer.

Analysis of cell free synthesis products. After the reaction mixture $(200 \mu \mathrm{l})$ containing $40 \mu \mathrm{Ci}$ of $\left[{ }^{3} \mathrm{H}\right]$ leucine was incubated for $90 \mathrm{~min}$ at $23^{\circ} \mathrm{C}$, the ribosomes were removed by centrifugation for $2 \mathrm{~h}$ at $100000 \times \mathrm{g}$. The postribosomal supernatant was subjected to Sephadex G-100 gel filtration $(1 \times 20 \mathrm{~cm})$. Fractions corresponding to the position of elution of standard 14-3-2 protein were obtained from columns. The pooled samples were concentrated by lyophilization and dialyzed against phosphate buffer saline (PBS) containing $0.1 \%$ unlabeled leucine. To $200 \mu \mathrm{l}$ of this mixture, $50 \mu \mathrm{l}$ of rabbit anti-143-2 protein antiserum and then $50 \mu \mathrm{g}$ of rat 14-3-2 protein were added and the reaction mixture was incubated at $37^{\circ} \mathrm{C}$ for $1 \mathrm{~h}$, followed by standing for $24 \mathrm{~h}$ at $4^{\circ} \mathrm{C}$. The precipitates were collected by centrifugation over a cushion of $1.0 \mathrm{M}$ sucrose at $50000 \times \mathrm{g}$ for $30 \mathrm{~min}$ at $4^{\circ} \mathrm{C}$. The precipitates were washed three times with cold PBS and then were dissolved in $100 \mu \mathrm{l}$ of $2 \%$ SDS, $1 \%$ 2-mercaptoethanol, $10 \%$ glycerol, $10 \mathrm{mM}$ Tris- $\mathrm{HCl}(\mathrm{pH} 6.8)$ at $70^{\circ} \mathrm{C}$ for $30 \mathrm{~min}$ and electrophoresed in SDS-polyacrylamide gels $(3.5 \%$ stacking gel; $10 \%$ resolving gel) in a discontinuous buffer system. ${ }^{10)}$ Pure 14-3-2 protein was run in parallel with the samples. The gels were stained with Coomassie brilliant blue by the method of Weber and Osborn. ${ }^{11)}$ The stained gels were cut into $2 \mathrm{~mm}$ slices. The slices were placed in counting vials with $1 \mathrm{ml}$ of NCS at $45^{\circ} \mathrm{C}$ overnight and then counted in a toluene-PPO scintillator.

Analysis of the newly synthesized proteins was performed by fluorography by Bonner and Laskey. ${ }^{12)}$ 
Sucrose density gradient centrifugation. Density gradient centrifugation was used to determine the size of poly (A)-containing polysomal RNA. Poly (A)-containing RNA (20-40 $\mu \mathrm{g}$ RNA) were dissolved in $10 \mathrm{mM}$ Tris-HCl $(\mathrm{pH} \mathrm{7.6}), 2 \mathrm{mM}$ EDTA, $0.5 \%$ SDS and layered onto a 5-25\% linear sucrose gradient and centrifuged in Hitachi RPS 25-3 rotor at $77500 \times \mathrm{g}$ for $6 \mathrm{~h}$ at $20^{\circ} \mathrm{C}$. Ultraviolet analysis was continuously carried out at $254 \mathrm{~nm}$ using an ISCO gradient fractionator Model 640 and Model UV-5.

Results. Our preparation of 14-3-2 protein gave a single band on Disc and SDS gel electrophoresis and had enolase activity. The antiserum against 14-3-2 protein was subjected to Ouchterlony immunodiffusion against a number of rat organ extracts. Only brain and spinal cord extracts gave a single precipitin line, indicating the specificity of 14-3-2 protein to the nervous system (data not shown). Analysis of rat brain poly (A)-containing polysomal RNA by sucrose density gradient centrifugation showed a heterogeneous pattern mainly distributed from about $9 \mathrm{~S}$ to $32 \mathrm{~S}$ with a peak of $19 \mathrm{~S}$. The pattern of rat liver poly (A)-containing polysomal RNA was similar to that of brain except for having a peak of $18 \mathrm{~S}$ (data not shown). Characteristics of the wheat germ proteins synthesizing system were examined. The addition of exogenous brain poly (A)-containing RNA to the incubation mixture resulted in a linear incorporation of $\left[{ }^{3} \mathrm{H}\right]$ leucine into the acid insoluble protein fraction for about $90 \mathrm{~min}$ at $23^{\circ} \mathrm{C}$. The extent of stimulation by brain mRNA was about 5-7-fold over endogenous incorporation. Increasing the amount of added mRNA to about $30 \mu \mathrm{g} / \mathrm{ml}$ caused a linear increase in $\left[{ }^{3} \mathrm{H}\right]$ leucine incorporation into proteins. Brain rRNA did not stimulate $\left[{ }^{3} \mathrm{H}\right]$ leucine incorporation. In the case of our wheat germ system, $1.5 \mathrm{mM}$ magnesium acetate was optimal and $36 \mathrm{mM} \mathrm{KCl}$ concentration was optimal in the presence of $1.5 \mathrm{mM}$ magnesium acetate.

The newly synthesized proteins obtained from wheat germ cell free systems were analyzed with SDS polyacrylamide slab gel electrophoresis and fluorography (Fig. 1). The newly synthesized proteins from reactions programmed with brain mRNA were slightly smaller in molecular weight than those with liver mRNA. In the case of liver mRNA a radioactive band corresponding to albumin in molecular weight was observed. Products of endogenous synthesis were hardly detected on the fluorograph except at the front (data not shown).

In order to demonstrate 14-3-2 protein in wheat germ cell free system directed with brain polysomal $\mathrm{mRNA}$, the soluble proteins of reaction mixture were immunoprecipitated with antiserum specific for 14-3-2 protein and analyzed by SDS polyacrylamide gel electrophoresis (Fig. 2a). This result showed the presence of a peak of radio- 


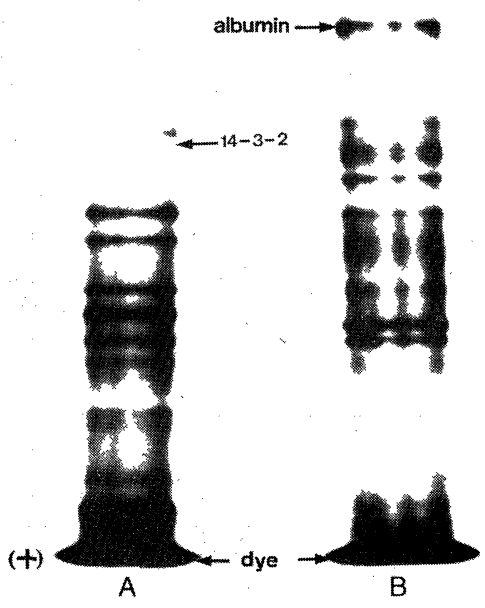

Fig. 1. Fluorograph of newly synthesized products of wheat germ cell free system directed with brain and liver mRNA. Aliquots of the postribosomal supernatants after incubation were electrophoresed in SDS polyacrylamide slab gels. The stained gels were exposed to Kodak RP Royal X-Omat film for 12 days at $-80^{\circ} \mathrm{C}$. A : Products directed with brain mRNA. B: Products directed with liver mRNA. Each sample containing about $3 \times 10^{4} \mathrm{cpm}$ was applied.

activity moving in a position corresponding to that of 14-3-2 protein. Another peak of radioactivity at the front comigrating with brom phenol blue may represent small peptides or nonspecific contamination, because each reaction product directed with brain mRNA, liver mRNA or endogenous reaction showed evidence of this peak. Heterogeneous mixtures with low radioactive peak were also observed and may represent incomplete peptide. These observations about the synthesis of 14-3-2 protein were further confirmed in a separate experiment. The SDS gel electrophoresis of the immunoprecipitates of the translation products was carried out. Then, band region of 14-3-2 protein from the gel was cut off and placed on top of the another SDS gel. After reelectrophoresis, gel was sliced and the radioactivity was determined. This experiment also showed a radioactive peak in a region corresponding to the band of 14-3-2 protein. However, the similar experiments with liver mRNA and endogenous reaction did not show any peak in the same gel region (Fig. 2b). The molecular weight of the radioactive peak was estimated to be approximately 46000 daltons and was identical to that of pure 14-3-2 protein. The relative amount of 14-3-2 protein synthesized was about $0.1 \%$ of soluble protein and did not change in the presence of varying concentration of $\mathrm{KCl}$.

Discussion. The biosynthesis of 14-3-2 protein in vitro was carried out using brain polysomal system by Zomzely-Neurath et al. ${ }^{13}$ ) However, no study on 14-3-2 protein biosynthesis in heterologous 
a

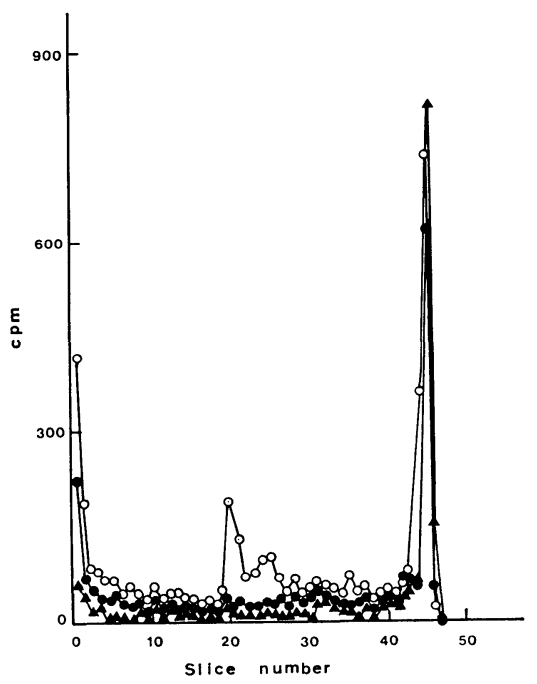

b

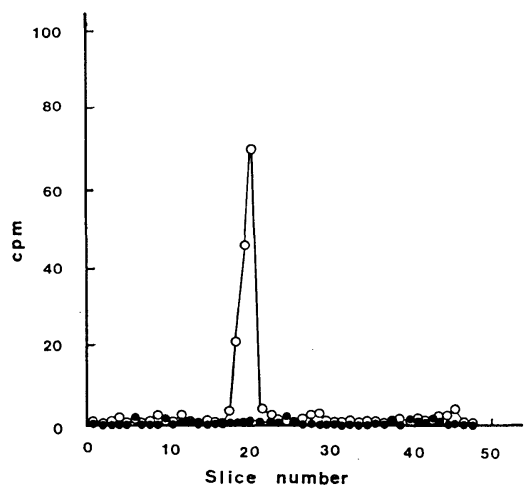

Fig. 2. SDS polyacrylamide gel electrophoresis of immunoprecipitated cell free translation products. a: Aliquots of the postribosomal supernatants after centrifugation of incubation mixture were treated with Sephadex G-100 as described in Methods. Total radioactivities in eluted fractions corresponding to position of 14-3-2 protein were $92000 \mathrm{cpm}$ for brain mRNA directed reaction, $75000 \mathrm{cpm}$ for liver mRNA directed reaction and $31000 \mathrm{cpm}$ for endogenous reaction. Then, these peptides were precipitated with 14-3-2 protein antiserum and carrier 14-3-2 protein. The immunoprecipitates were subjected to SDS gel electrophoresis. Gels were sliced in $2 \mathrm{~mm}$ and counted. The position of 143-2 protein was determined by electrophoresis of purified rat 14-3-2 protein in a parallel gel. $\mathrm{b}$ : Band regions of 14-3-2 protein from SDS gels in an experiment similar to experiment (a) were cut and placed on top of the other SDS gels. After running, gels were sliced and the radioactivity was determined. $\bigcirc-O$, reaction products with brain mRNA; $\bullet-\bullet$, reaction products with liver mRNA; $\mathbf{\Lambda}-\mathbf{\Lambda}$, endogenous reaction products.

cell free system directed with brain mRNA has been carried out. The translation in vitro of brain mRNA into tubulin, ${ }^{14)}$ actin $^{14)}$ and S-100 protein ${ }^{15)}$ has been described using a wheat germ cell free system. Our present report described that brain polysomal poly (A)containing RNA was able to be translated to 14-3-2 protein, a brain specific protein of molecular weight 46000 daltons in a wheat germ cell free system. With this brain mRNA, 14-3-2 protein accounted for $0.1 \%$ of the soluble protein synthesized. This percentage was similar to that of S-100 protein. The reasons for the considerably low translational rate may be attributed to the relatively high 
molecular weight of 14-3-2 protein and low concentration of mRNA for 14-3-2 protein. Our results exclude the necessity of brain specific initiation and elongation factors for translation of 14-3-2 protein mRNA, since our data show that the 14-3-2 protein can be synthesized in a heterologous cell free system directed with purified isolated brain polysomal mRNA as in the case of S-100 protein. We could not find any significant synthesis of 14-3-2 protein when the reaction was directed with liver mRNA. It is well known that 14-3-2 protein is a neuron-specific protein as described previously. Therefore, it may be very useful for studies of cell differentiation in the brain to examine mRNA for this protein. In the future studies, we are going to purify this mRNA and make complementary DNA to advance our study program on gene expression in the central nervous system. However, it will be very difficult to isolate pure mRNA for 14-3-2 protein, because the concentration of this protein is only about $1 \%$ of total soluble protein of rat brain. ${ }^{16)}$

\section{References}

1) Moore, B. W.: Advances in Neurochemistry (eds. Agranoff, B. W. and Aprison, M. H.), vol. 1, Plenum Press, New York, pp. 137-155 (1975).

2) Marangos, P. J., Zomzely-Neurath, C., and York, C.: Biochem. Biophys. Res. Commun., 68, 1309 (1976).

3) Marangos, P. J., Zis, A. P., Clark, R. L., and Goodwin, F. K.: Brain Res., 150, 117 (1978).

4) Grasso, A., Roda, G., Hogue-Angeletti, R. A., Moore, B. W., and Perez, V. J.: Brain Res., 124, 497 (1977).

5) Marangos, P. J., Zomzely-Neurath, C., Luk, D. C. M., and York, C.: J. Biol. Chem., 250, 1884 (1975).

6) Takahashi, Y., Mase, K., and Sugano, H.: Biochim. Biophys. Acta, 119, 627 (1966).

7) Perry, R. P., La Torre, J., Kelley, D. E., and Greenberg, J. R.: Biochim. Biophys. Acta, 262, 220 (1972).

8) Aviv, H., and Leder, P.: Proc. Natl. Acad. Sci., 69, 1408 (1972).

9) Roberts, B. E., and Patterson, B. M.: Proc. Natl. Acad. Sci., 70, 2330 (1973).

10) Laemmli, U. K.: Nature, 227, 680 (1970).

11) Weber, K., and Osborn, M.: J. Biol. Chem., 244, 4406 (1969).

12) Bonner, W. M., and Laskey, R. A.: Eur. J. Biochem., 46, 83 (1974).

13) Zomzely-Neurath, C., York, C., and Moore, B. W.: Arch. Biochem. Biophys., 155, 58 (1973).

14) Gozes, I., Schmitt, H., and Littauer, U. Z.: Proc. Natl. Acad. Sci., 72, 701 (1975).

15) Mahony, J., Brown, I., Labourdetti, G., and Marks, A.: Eur. J. Biochem., 67, 203 (1976).

16) Marangos, P. J., Zomzely-Neurath, C., and Goodwin, F. K.: J. Neurochem., 28, 1097 (1977). 